\title{
Reference Type Code
}

National Cancer Institute

\section{Source}

National Cancer Institute. Reference Type Code. NCI Thesaurus. Code C95346.

A coded value specifying the reference type. 